\title{
Implementasi Algoritma Negascout Untuk Permainan Checkers
}

\author{
Aditya Kurniawan Effendi ${ }^{1}$
}

aditya.kurniawan.eff@gmail.com

\author{
Rosa Delima ${ }^{2}$ \\ rosadelima@ukdw.ac.id
}

Antonius R. C. ${ }^{3}$
anton@ti.ukdw.ac.id

\begin{abstract}
Checker is a zero sum game which means if one player is declared win then the other player is declared lose, if one player gets 1 point then the other player gets -1 point. In this type of game every player have full knowledge of other player condition, like every move the other player has, what kind of pawn and the position of other player's pawn.

This game will be implemented with Negascout and compared to Alpha-Beta to see wether it offer better or worse performance than Alpha-Beta. Both algorithm will be given 5 identical board condition to solve and the search depth will be limited to 4, 6 and 8 level.

The result showed Negascout outperformed Alpha-Beta on $86 \%$ of the test performed. It searched less node than Alpha-Beta especially with depth 8. The result also showed Negascout found one difference node solution compared to Alpha-Beta with identical heuristic score. Negascout returned identical heuristic score with Alpha-Beta on all test.
\end{abstract}

Kata Kunci : Negascout, Permainan, Checkers, Kecerdasan Buatan

\section{PENDAHULUAN}

Seiring dengan berkembangnya teknologi komputer, teknologi perangkat lunak juga berkembang. Salah satu teknologi perangkat lunak yang berkembang adalah aplikasi permainan. Dewasa ini sudah bermunculan berbagai macam jenis aplikasi permainan. Dari permainan klasik seperti kartu, board games, sampai permainan-permainan lainnya yang lebih kompleks.

Semua permainan itu diperlukan sebuah kecerdasan yang memungkinkan komputer untuk bermain melawan manusia. Cabang ilmu komputer yang berusaha untuk menirukan kecerdasan manusia adalah kecerdasan buatan atau Artificial Intelligence (A.I.). Salah satu permainan yang menggunakan A.I. adalah checkers, Pada permainan ini pemain dinyatakan menang jika pemain lain kalah, seandainya pemain membutuhkan 1 poin untuk menang, maka untuk kalah pemain membutuhkan poin -1. Permainan seperti ini disebut juga dengan zero-sum game yang berarti kemenangan pemain adalah kekalahan pemain lainnya. Dalam permainan ini setiap pemain dapat mengetahui semua kondisi permainan, seperti jumlah bidak yang dimiliki pemain dan lawan, posisi bidak, dan langkah apa saja yang dimiliki oleh pemain maupun lawan. Oleh karena itu maka

\footnotetext{
${ }^{1}$ Teknik Informatika, Fakultas Teknologi Informasi, Universitas Kristen Duta Wacana, Yogyakarta

${ }^{2}$ Teknik Informatika, Fakultas Teknologi Informasi, Universitas Kristen Duta Wacana, Yogyakarta

${ }^{3}$ Teknik Informatika, Fakultas Teknologi Informasi, Universitas Kristen Duta Wacana, Yogyakarta
} 
permainan checkers ini sangat cocok jika mengimplementasikan algoritma negascout untuk penentuan langkah komputer. Negascout ditemukan oleh Alexander Reinefeld tahun 1983. Algoritma ini berusaha memotong node-node dengan melihat dahulu node yang akan dicek, apabila node tersebut memiliki nilai yang lebih baik maka akan dilakukan pencarian ulang dengan menggunakan search window seperti algoritma alpha-beta pruning untuk mengetahui nilai asli dari node tersebut.

\section{LANDASAN TEORI}

\subsection{Negascout}

Negascout merupakan optimalisasi minimax dengan mempersempit ruang pencarian (minimal search window), dengan semakin sempitnya selisih nilai alpha dan beta maka semakin besar kemungkinan terjadinya pemotongan pencarian. Negascout memiliki dasar bahwa langkah-langkah setelah langkah pertama akan menghasilkan pemotongan, maka mengevaluasi semua langkah adalah sia-sia. Negascout akan mengecek dengan null window terlebih dahulu yang dinotasikan dengan $\mathrm{m}$ dan $\mathrm{n}$ dimana $\mathrm{m}$ adalah batas atas dan $\mathrm{n}$ adalah batas bawah, null window memiliki batas atas dan bawah yang bersilisih satu. Ketika sebuah node memiliki nilai yang lebih tinggi dari m maka akan dilakukan pencarian ulang dengan menggunakan window yang lebih besar untuk mengetahui nilai yang terbaik.

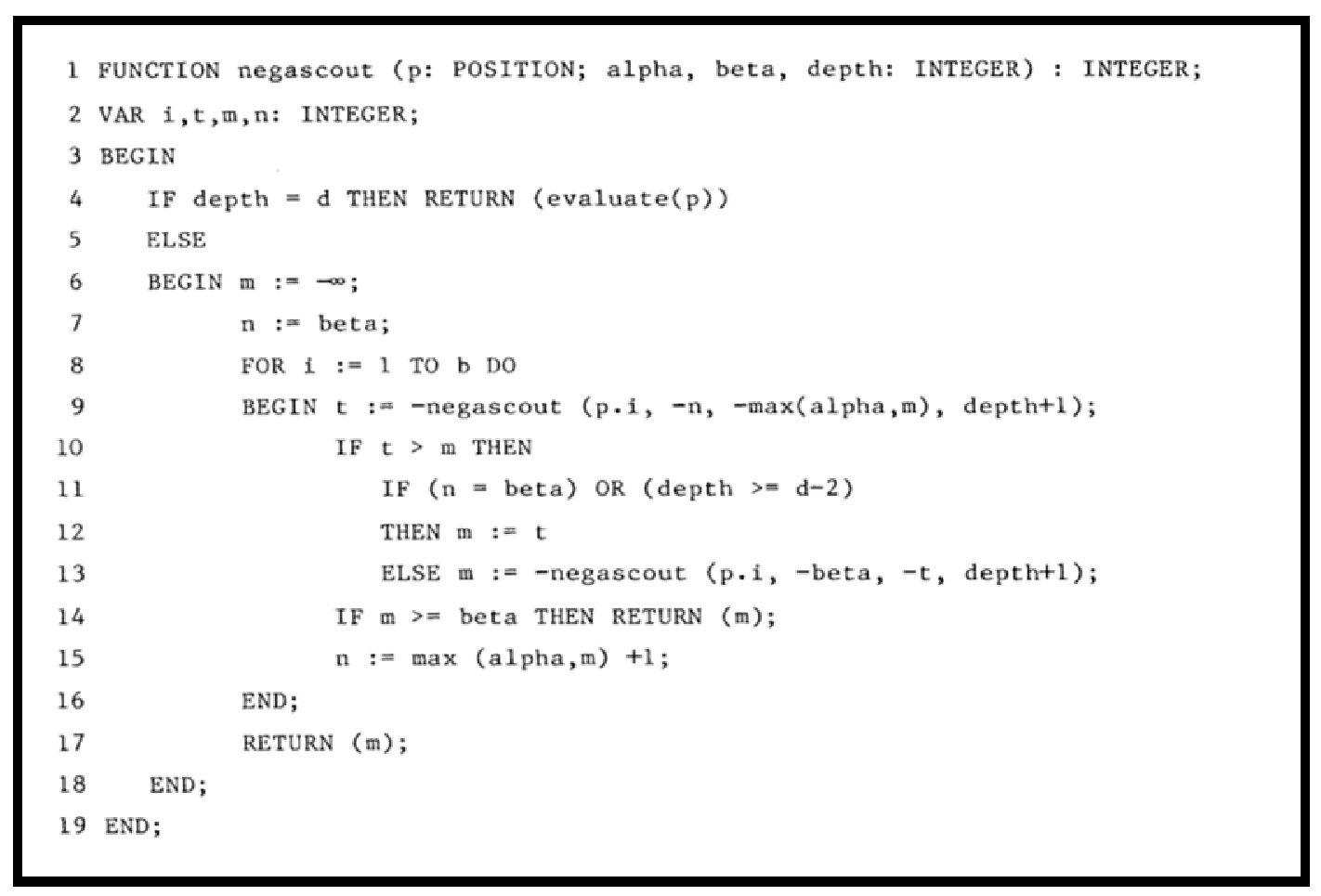

Gambar 1. PseudocodeNegascout Dikutip dari: Reinefeld, A. (1983) 
Gambar 1. merupakan pseudocode untuk algoritma Negascout, berdasarkan algoritma diatas dapat dijelaskan cara kerja algoritma negascout sebagai berikut, statement pertama sama seperti alpha-beta, yaitu jika posisi $\mathrm{p}$ adalah node leaf maka negascout akan mengembalikan nilai fungsi evaluasi (baris 4). Selain itu variable $m$ dan $n$ diinisialisasi dengan $-\infty$ dan beta (baris 6 dan 7). Kemudian negascout akan melakukan "scout" pada node anak dari p dari kiri ke kanan. Node anak paling kiri akan dicari dengan menggunakan interval (-beta,-alpha) dan anak lainnya dicari dengan zero-width window (-m-1, -m) yang sudah diisi pada baris 15 sesudah melakukan pencarian anak paling kanan, karena null window ini tidak memiliki elemen, maka pencarian pasti akan gagal. Arah dari kegagalan ini menunjukkan apakah node tersebut dapat dipotong atau tidak.

Jika null window gagal karena $\mathrm{t}>\mathrm{m}$ (baris 10), negascout harus mengecek kembali node tersebut dengan search window yang lebih lebar untuk mengetahui nilai aslinya. Hanya terdapat dua kasus dimana tidak diperlukan pencarian ulang yaitu, ketika n=beta (baris 11), dan negascout's "failsoft refinement"selalu mengembalikan nilai minimax yang benar pada dua level terbawah. Pada kasus lainnya pencarian ulang harus dilakukan dengan menggunakan search window baru yaitu (-beta,-t) (baris 13).

Kondisi untuk pemotongan (baris 14) sama seperti alpha-beta : jika $\mathrm{m} \geq$ beta maka semua node anak lain dapat diabaikan.

\subsection{Checkers}

Checkers atau draught adalah board games yang pertama kali dimainkan sekitar 3000 tahun sebelum masehi, pada saat itu papan yang dan jumlah bidak yang digunakan berbeda dengan checkers yang kita kenal sekarang.

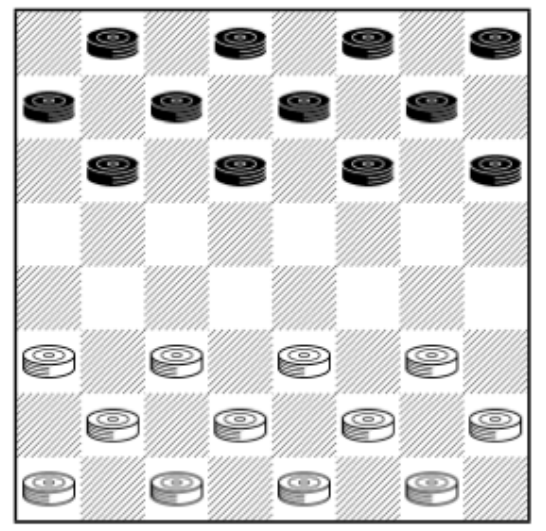

Gambar 2. Papan Checker Dikutip dari: Reinefeld, F. (2011)

Checkers yang akan penulis gunakan untuk tugas akhir ini merupakan English checkers dimana papan yang digunakan berukuran 8x8 (memiliki jumlah total 64 kotak) dengan 12 bidak pada setiap sisi (total 24 bidak). 
Berdasarkan buku How to Win at Checkers, setiap pemain menyusun 12 bidaknya pada papan permainan pada kotak gelap di 3 baris paling dekat dengan pemain. Baris paling dekat dengan pemain disebut dengan crownhead atau king's row. Pemain dengan warna bidak gelap bergerak dahulu.

Ada 2 jenis gerakan dalam permainan ini yaitu :

1. Simple move yaitu gerakan diagonal satu langkah ke kotak kosong di depan.

2. Jump move yaitu gerakan diagonal melompati satu bidak lawan ke kotak kosong di depan. Bidak yang dilompati akan dihilangkan dari papan. Apabila terdapat jump move setelah gerakan jump move, pemain harus melakukan gerakan tersebut sampai tidak terdapat jump move lagi.

Ketika pemain memiliki kesempatan untuk melakukan jump move, pemain harus melakukan gerakan itu. Apabila pemain memiliki beberapa gerakan jump move, pemain bebas memilih jump move mana yang akan diambil.

Checkers memiliki dua jenis bidak, yaitu :

1. Bidak manusia. Bidak manusia hanya dapat bergerak ke depan. Ketika bidak manusia mencapai king's row, bidak tersebut akan berubah menjadi bidak raja.

2. Bidak raja. Bidak raja dapat bergerak ke depan dan ke belakang.

Permainan berakhir apabila salah satu pemain tidak dapat melakukan pergerakan atau kehilangan semua bidaknya.

\subsection{Fungsi Evaluasi}

Dalam mengambil keputusan untuk menentukan langkah yang diambil, komputer membutuhkan sebuah fungsi untuk menilai untung atau tidaknya suatu langkah. Setiap permainan memiliki fungsi evaluasi yang berbeda-beda. Dalam penelitian ini fungsi evaluasi akan dipengaruhi oleh beberapa faktor, yaitu : jumlah bidak, jumlah langkah yang tersedia, jumlah lompatan yang tersedia dan jumlah bidak di pinggir papan.

\section{HASIL DAN PEMBAHASAN}

Pada Gambar 3 , dapat dilihat algoritma negascout dalam permainan checkers. Penelitian ini akan dilakukan 2 pengujian. Pengujian pertama dilakukan untuk melihat performa Negascout dibandingkan dengan Alpha-Beta Pruning. Pengujian kedua dilakukan untuk melihat performa Negascout untuk permainan Checkers. 


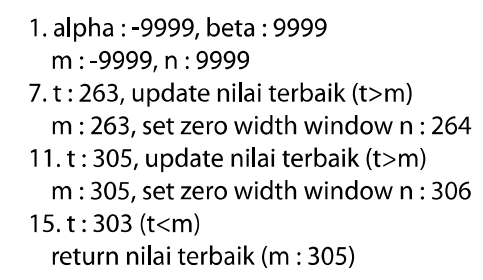

P (305)

MAX

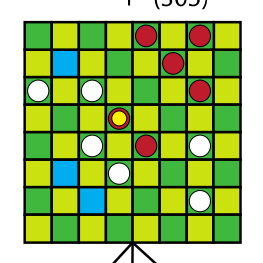

2. alpha : -9999 , beta : 9999

$\mathrm{m}:-9999, \mathrm{n}: 9999$

4. $t:-263$, update nilai terbaik $(t>m)$

$m:-263$, set zero width window $n:-262$

6. $\mathrm{t}:-305$, nilai tidak diupdate karena $(\mathrm{t}<\mathrm{ph}$ ) return nilai terbaik ( $m:-263$ )

MIN

MAX
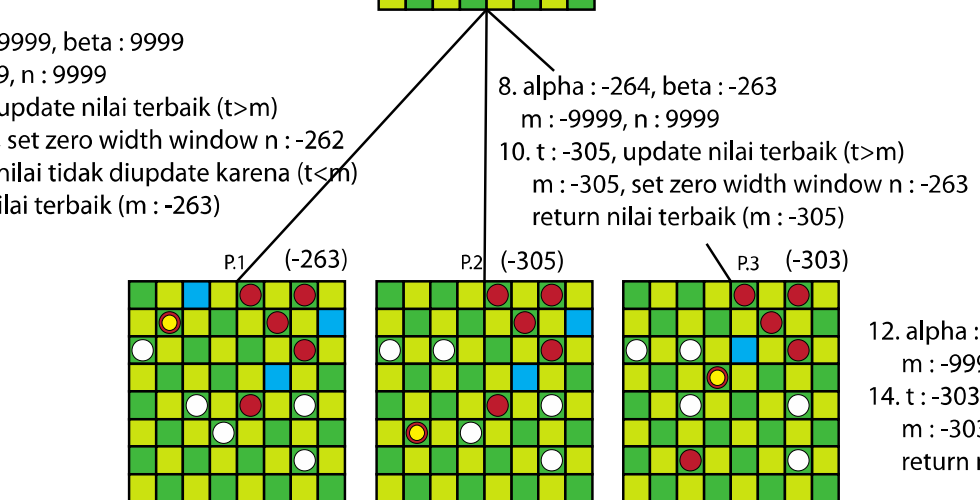

P.2 $(-305)$

P.3 $\quad(-303)$
( 305$)$

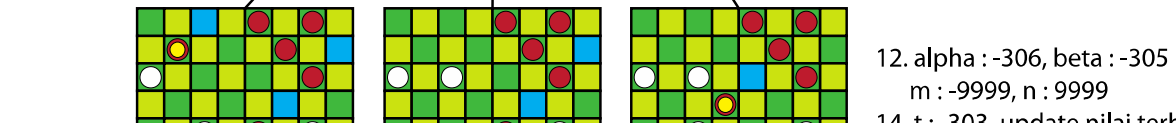

14. $t:-303$, update nilai terbaik $(t>m)$

$m:-303$, pruning $(m>$ beta)

return nilai terbaik $(m: 303)$

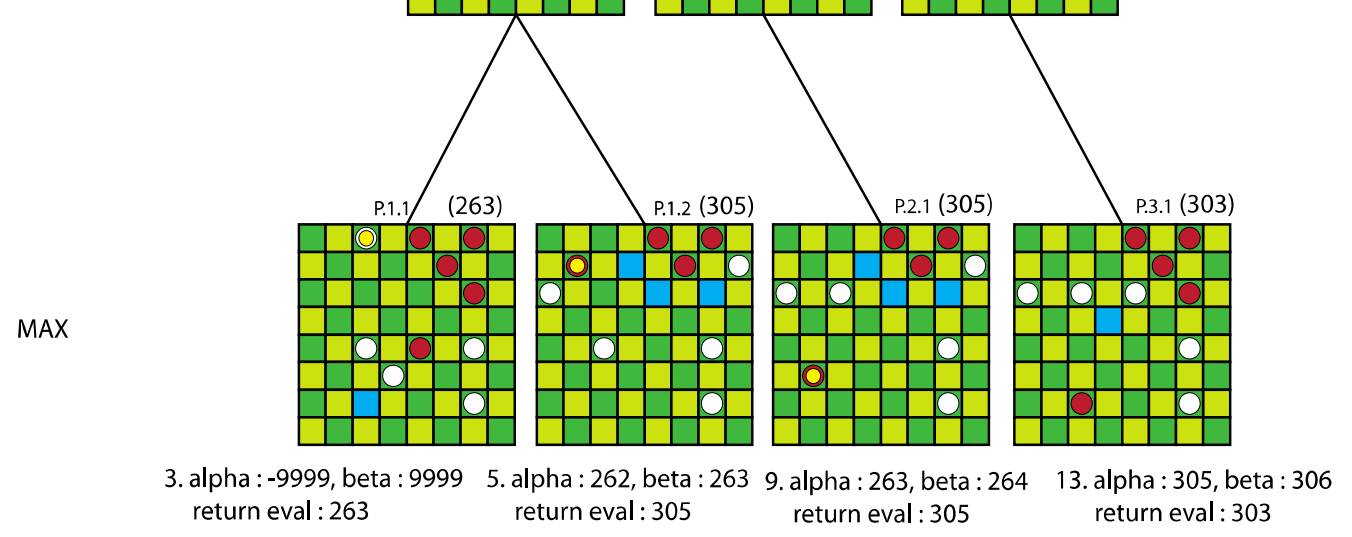

Gambar 3. Negascout dalam Permainan Checkers

Pengujian pertama akan dilakukan dengan memberikan 5 kondisi papan yang berbeda dengan 3 kedalaman yang berbeda. Setiap kondisi papan akan dilakukan pencarian solusi dengan menggunakan kedua algoritma sebanyak 3 kali. Dari pengujian akan dicatat waktu (dalam ms), node solusi, jumlah node dan nilai heuristiknya.

Kondisi papan yang diberikan untuk pengujian ini adalah sebagai berikut :

1. Kondisi papan pertama

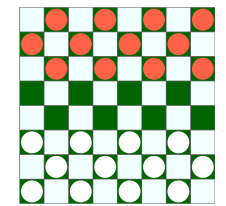

2. Kondisi papan kedua

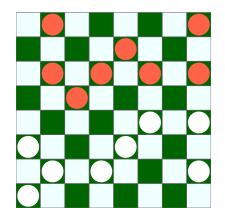

3. Kondisi papan ketiga

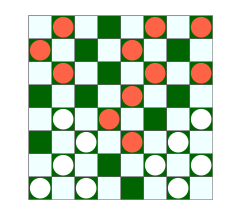



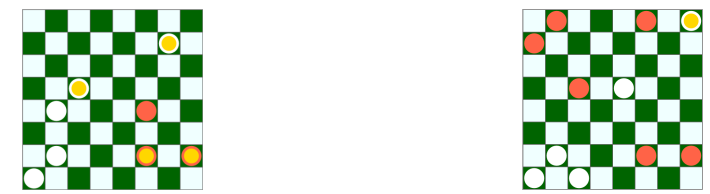

Pengujian kedua dilakukan untuk mengetahui performa Negascout dalam permainan checkers. Pada pengujian ini user memainkan bidak merah dan komputer (Negascout) memainkan bidak putih. Pengujian dilakukan dengan menggunakan depth 4 dan 6, masing-masing depth dilakukan pengujian sebanyak 5 kali.

\section{EVALUASI}

\subsection{Hasil Pengujian Perbandingan Negascout dengan Alpha-Beta Pruning}

Pengujian dilakukan untuk kedalaman 4, 6, dan 8. Masing-masing hasil pengujian dapat dilihat pada tabel 1, tabel 2, dan tabel 3.

Tabel 1.

Perbandingan Negascout dan Alpha-Beta Dengan Depth 4

\begin{tabular}{|c|c|c|c|c|c|c|c|c|c|}
\hline \multirow{2}{*}{ Kondisi } & \multirow{2}{*}{ No. } & \multicolumn{4}{|c|}{ Negascout } & \multicolumn{4}{|c|}{ Alpha-Beta Pruning } \\
\hline & & $\begin{array}{c}\text { Jumlah } \\
\text { Node }\end{array}$ & $\begin{array}{c}\text { Waktu } \\
(\mathrm{ms})\end{array}$ & $\begin{array}{l}\text { Node } \\
\text { Solusi }\end{array}$ & Nilai & $\begin{array}{c}\text { Jumlah } \\
\text { Node }\end{array}$ & $\begin{array}{c}\text { Waktu } \\
(\mathrm{ms})\end{array}$ & $\begin{array}{l}\text { Node } \\
\text { Solusi }\end{array}$ & Nilai \\
\hline \multirow{3}{*}{1} & 1. & 281 & 1.004 & P.1.2.1.1 & 679 & 442 & 1.736 & P.1.2.1.1 & 679 \\
\hline & 2. & 281 & 996 & P.1.2.1.1 & 679 & 442 & 1.637 & P.1.2.1.1 & 679 \\
\hline & 3. & 281 & 1.002 & P.1.2.1.1 & 679 & 442 & 1.734 & P.1.2.1.1 & 679 \\
\hline \multirow{3}{*}{2} & 1. & 275 & 881 & P.4.2.1.1 & 436 & 262 & 872 & P.4.2.1.1 & 436 \\
\hline & 2. & 275 & 873 & P.4.2.1.1 & 436 & 262 & 827 & P.4.2.1.1 & 436 \\
\hline & 3. & 275 & 854 & P.4.2.1.1 & 436 & 262 & 844 & P.4.2.1.1 & 436 \\
\hline \multirow{3}{*}{3} & 1. & 347 & 1.302 & P.5.4.1.1 & 662 & 369 & 1.418 & P.5.4.1.1 & 662 \\
\hline & 2. & 347 & 1.288 & P.5.4.1.1 & 662 & 369 & 1.356 & P.5.4.1.1 & 662 \\
\hline & 3. & 347 & 1.247 & P.5.4.1.1 & 662 & 369 & 1.369 & P.5.4.1.1 & 662 \\
\hline \multirow{3}{*}{4} & 1. & 396 & 791 & P.2.1.2.1 & 232 & 431 & 932 & P.2.1.2.1 & 232 \\
\hline & 2. & 396 & 811 & P.2.1.2.1 & 232 & 431 & 889 & P.2.1.2.1 & 232 \\
\hline & 3. & 396 & 818 & P.2.1.2.1 & 232 & 431 & 893 & P.2.1.2.1 & 232 \\
\hline \multirow{3}{*}{5} & 1. & 765 & 1.695 & $\begin{array}{l}\text { P.9.1.1.1 } \\
\end{array}$ & 557 & 851 & 1.917 & P.9.1.1.1 & 557 \\
\hline & 2. & 765 & 1.749 & P.9.1.1.1 & 557 & 851 & 1.929 & P.9.1.1.1 & 557 \\
\hline & 3. & 765 & 1.695 & P.9.1.1.1 & 557 & 851 & 1.944 & P.9.1.1.1 & 557 \\
\hline
\end{tabular}


Pada tabel 1 dapat dilihat Negascout menghasilkan pohon pencarian lebih sedikit dibandingkan dengan Alpha-Beta Pruning kecuali pada kondisi papan nomor 2. Waktu yang dibutuhkan untuk menemukan solusi berbanding lurus dengan jumlah node yang dihasilkan.

Tabel 2.

Perbandingan Negascout dan Alpha-Beta Dengan Depth 6

\begin{tabular}{|c|c|c|c|c|c|c|c|c|c|}
\hline \multirow{3}{*}{ Kondisi } & \multirow{2}{*}{ No. } & \multicolumn{9}{|c|}{ Jumlah } & $\begin{array}{c}\text { Waktu } \\
\text { Node }\end{array}$ & $(\mathbf{m s})$ & Node Solusi & Nilai & $\begin{array}{c}\text { Jumlah } \\
\text { Node }\end{array}$ & $\begin{array}{c}\text { Waktu } \\
(\mathbf{m s})\end{array}$ & Node Solusi & Nilai \\
\hline \multirow{3}{*}{1} & 1. & 2.154 & 8.082 & P.1.2.1.1.2.1 & 679 & 3.192 & 12.724 & P.1.2.1.1.2.1 & 679 \\
\cline { 2 - 10 } & 2. & 2.154 & 8.159 & P.1.2.1.1.2.1 & 679 & 3.192 & 12.681 & P.1.2.1.1.2.1 & 679 \\
\cline { 2 - 10 } & 3. & 2.154 & 7.871 & P.1.2.1.1.2.1 & 679 & 3.192 & 12.714 & P.1.2.1.1.2.1 & 679 \\
\hline \multirow{3}{*}{2} & 1. & 1.297 & 3.966 & P.1.2.1.1.2.1 & 436 & 1.853 & 5.835 & P.1.2.1.1.2.1 & 436 \\
\cline { 2 - 10 } & 2. & 1.297 & 3.943 & P.1.2.1.1.2.1 & 436 & 1.853 & 5.800 & P.1.2.1.1.2.1 & 436 \\
\cline { 2 - 10 } & 3. & 1.297 & 3.939 & P.1.2.1.1.2.1 & 436 & 1.853 & 5.813 & P.1.2.1.1.2.1 & 436 \\
\hline \multirow{3}{*}{3} & 1. & 1.767 & 6.446 & P.4.5.1.2.5.1 & 562 & 2.064 & 7.548 & P.4.5.1.2.5.1 & 562 \\
\cline { 2 - 10 } & 2. & 1.767 & 6.356 & P.4.5.1.2.5.1 & 562 & 2.064 & 7.573 & P.4.5.1.2.5.1 & 562 \\
\cline { 2 - 10 } & 3. & 1.767 & 6.451 & P.4.5.1.2.5.1 & 562 & 2.064 & 7.601 & P.4.5.1.2.5.1 & 562 \\
\hline \multirow{3}{*}{4} & 1. & 1.947 & 3.931 & P.1.7.1.10.1.1 & 310 & 1.820 & 3.293 & P.1.7.1.10.1.1 & 310 \\
\cline { 2 - 10 } & 2. & 1.947 & 3.927 & P.1.7.1.10.1.1 & 310 & 1.820 & 3.284 & P.1.7.1.10.1.1 & 310 \\
\cline { 2 - 10 } & 3. & 1.947 & 3.984 & P.1.7.1.10.1.1 & 310 & 1.820 & 3.303 & P.1.7.1.10.1.1 & 310 \\
\hline \multirow{3}{*}{5} & 1. & 5.142 & 11.913 & P.8.2.4.2.1.1 & 515 & 6.132 & 13.765 & P.8.2.7.2.1.1 & 515 \\
\cline { 2 - 9 } & 2. & 5.142 & 11.419 & P.8.2.4.2.1.1 & 515 & 6.132 & 13.758 & P.8.2.7.2.1.1 & 515 \\
\cline { 2 - 9 } & 3. & 5.142 & 11.522 & P.8.2.4.2.1.1 & 515 & 6.132 & 13.724 & P.8.2.7.2.1.1 & 515 \\
\hline
\end{tabular}

Pengujian kedua dengan depth 6 juga menunjukkan pohon pencarian dan waktu yang dihasilkan Negascout lebih kecil dibandingkan dengan Alpha-Beta Pruning. Dari 5 kondisi yang diujikan Negascout menghasilkan node solusi yang sama dengan Alpha-Beta Pruning pada kondisi 1 sampai 4. Negascout menghasilkan solusi yang berbeda pada kondisi 5 dengan nilai heuristik yang sama. Pada kondisi nomor 4 Negascout menghasilkan jumlah node yang lebih banyak daripada Alpha-Beta Pruning.

Pengujian ketiga membatasi pohon pencarian pada kedalaman 8. Hasil pengujian memperlihatkan Negascout menghasilkan jumlah node yang lebih sedikit pada semua kondisi pengujian dengan solusi yang sama dengan Alpha-Beta Pruning 
Tabel 3.

Perbandingan Negascout dan Alpha-Beta Dengan Depth 8

\begin{tabular}{|c|c|c|c|c|c|c|c|c|c|}
\hline \multirow{3}{*}{ Kondisi } & \multirow{2}{*}{ No. } & \multicolumn{9}{|c|}{ Negascout } & \multicolumn{4}{|c|}{ Alpha-Beta Pruning } \\
\cline { 3 - 10 } & Node & $\begin{array}{c}\text { Waktu } \\
(\mathbf{m s})\end{array}$ & Node Solusi & Nilai & $\begin{array}{c}\text { Jumlah } \\
\text { Node }\end{array}$ & $\begin{array}{c}\text { Waktu } \\
(\mathbf{m s})\end{array}$ & Node Solusi & Nilai \\
\hline \multirow{3}{*}{1} & 1. & 10.964 & 42.355 & P.1.2.1.2.2.2.1.1 & 619 & 24.288 & 93.497 & P.1.2.1.2.2.2.1.1 & 619 \\
\cline { 2 - 10 } & 2. & 10.964 & 42.622 & P.1.2.1.2.2.2.1.1 & 619 & 24.288 & 94.252 & P.1.2.1.2.2.2.1.1 & 619 \\
\cline { 2 - 10 } & 3. & 10.964 & 41.828 & P.1.2.1.2.2.2.1.1 & 619 & 24.288 & 94.210 & P.1.2.1.2.2.2.1.1 & 619 \\
\hline \multirow{3}{*}{2} & 1. & 8.309 & 25.537 & P.1.2.1.1.2.1.3.1 & 436 & 13.064 & 40.150 & P.1.2.1.1.2.1.3.1 & 436 \\
\cline { 2 - 10 } & 2. & 8.309 & 24.123 & P.1.2.1.1.2.1.3.1 & 436 & 13.064 & 39.783 & P.1.2.1.1.2.1.3.1 & 436 \\
\cline { 2 - 10 } & 3. & 8.309 & 25.541 & P.1.2.1.1.2.1.3.1 & 436 & 13.064 & 41.078 & P.1.2.1.1.2.1.3.1 & 436 \\
\hline \multirow{3}{*}{3} & 1. & 8.965 & 32.410 & P.2.1.5.1.1.3.1.1 & 594 & 10.083 & 36.773 & P.2.1.5.1.1.3.1.1 & 594 \\
\cline { 2 - 10 } & 2. & 8.965 & 32.576 & P.2.1.5.1.1.3.1.1 & 594 & 10.083 & 36.575 & P.2.1.5.1.1.3.1.1 & 594 \\
\cline { 2 - 10 } & 3. & 8.965 & 32.702 & P.2.1.5.1.1.3.1.1 & 594 & 10.083 & 37.246 & P.2.1.5.1.1.3.1.1 & 594 \\
\hline \multirow{3}{*}{4} & 1. & 55.831 & 118.111 & P.2.1.2.1.1.1.1.1 & 334 & 64.181 & 145.078 & P.2.1.2.1.1.1.1.1 & 334 \\
\cline { 2 - 9 } & 2. & 55.831 & 117.614 & P.2.1.2.1.1.1.1.1 & 334 & 64.181 & 146.440 & P.2.1.2.1.1.1.1.1 & 334 \\
\cline { 2 - 9 } & 3. & 55.831 & 117.881 & P.2.1.2.1.1.1.1.1 & 334 & 64.181 & 147.011 & P.2.1.2.1.1.1.1.1 & 334 \\
\hline \multirow{3}{*}{5} & 1. & 33.825 & 76.670 & P.4.2.10.4.8.5.5.1 & 579 & 42.725 & 99.003 & P.4.2.10.4.8.5.5.1 & 579 \\
\cline { 2 - 9 } & 2. & 33.825 & 75.907 & P.4.2.10.4.8.5.5.1 & 579 & 42.725 & 100.045 & P.4.2.10.4.8.5.5.1 & 579 \\
\cline { 2 - 9 } & 3. & 33.825 & 75.969 & P.4.2.10.4.8.5.5.1 & 579 & 42.725 & 98.924 & P.4.2.10.4.8.5.5.1 & 579 \\
\hline
\end{tabular}

\subsection{Hasil Pengujian User Melawan Negascout dan Alpha-Beta Pruning}

Pengujian ini dilakukan oleh 2 user melawan komputer dengan menggunakan algoritma Negascout dan Alpha-Beta Pruning dengan depth 4, 6 dan 8 sebanyak masing-masing 10 kali permainan. Pengalaman user dalam pengujian ini satu user masih pemula dan satu user memiliki pengalaman bermain selama 10 tahun. Pemain dengan pengalaman bermain lebih lama akan memainkan pengujian nomor 1 sampai 5 dan pemain pemula memainkan pengujian nomor 6 sampai dengan 10.

Dari pengujian yang dilakukan komputer menggunakan Negascout memiliki persentase kemenangan $60 \%$ pada depth 4 dan $80 \%$ pada depth 6 . Pada depth 8 pemain menghentikan permainan karena waktu tunggu yang terlalu lama (pencarian solusi komputer lebih dari 1 menit) sehingga hasil pengujian depth 8 tidak dimasukkan. Dengan menggunakan Alpha-Beta Pruning komputer miliki persentase kemenangan $50 \%$ dan $70 \%$ pada depth 4 dan 6. 
Tabel 4.

Hasil Pengujian User Melawan Negascout

\begin{tabular}{|c|c|c|c|c|c|}
\hline \multirow{2}{*}{ Depth } & \multirow{2}{*}{ No. } & \multicolumn{4}{|c|}{ Pemenang } \\
\hline & & Negascout & User & Alpha-Beta & User \\
\hline \multirow{10}{*}{4} & 1. & $\checkmark$ & - & - & $\checkmark$ \\
\hline & 2. & $\checkmark$ & - & $\checkmark$ & - \\
\hline & 3. & $\checkmark$ & - & $\checkmark$ & - \\
\hline & 4. & - & $\checkmark$ & - & $\checkmark$ \\
\hline & 5. & - & $\checkmark$ & - & $\checkmark$ \\
\hline & 6. & $\checkmark$ & - & $\checkmark$ & - \\
\hline & 7. & $\checkmark$ & - & $\checkmark$ & - \\
\hline & 8. & - & $\checkmark$ & - & $\checkmark$ \\
\hline & 9. & - & $\checkmark$ & - & $\checkmark$ \\
\hline & 10. & $\checkmark$ & & $\checkmark$ & \\
\hline \multirow{10}{*}{6} & 1. & $\checkmark$ & - & $\checkmark$ & - \\
\hline & 2. & - & $\checkmark$ & - & $\checkmark$ \\
\hline & 3. & $\checkmark$ & - & - & $\checkmark$ \\
\hline & 4. & - & $\checkmark$ & - & $\checkmark$ \\
\hline & 5. & $\checkmark$ & - & $\checkmark$ & - \\
\hline & 6. & $\checkmark$ & - & $\checkmark$ & - \\
\hline & 7. & $\checkmark$ & - & $\checkmark$ & - \\
\hline & 8. & $\checkmark$ & - & $\checkmark$ & - \\
\hline & 9. & $\checkmark$ & - & $\checkmark$ & - \\
\hline & 10 . & $\checkmark$ & - & $\checkmark$ & - \\
\hline
\end{tabular}

\section{KESIMPULAN DAN SARAN}

\subsection{Kesimpulan}

Berdasarkan implementasi serta setalah melakukan analisa algoritma Negascout pada permainan Checkers didapatkan kesimpulan sebagai berikut:

a) Dari semua pengujian yang dilakukan $86 \%$ hasil pengujian menunjukkan penerapan algoritma Negascout pada permainan Checkers menghasilkan jumlah node yang lebih sedikit dan waktu pencarian yang lebih singkat dibandingkan dengan algoritma Alpha-Beta Pruningterutama pada depth 8. 
b) Melihat dari nilai heuristik yang dihasilkan algoritma Negascout pada pengujian yang dilakukan algoritma ini menghasilkan solusi yang sama dengan algoritma Alpha-Beta Pruning

c) Apabila algoritma Negascout melakukan pencarian ulang pada level-level awal, maka algoritma ini akan mengecek ulang semua anak node dari node yang dilakukan pencarian ulang. Apabila pencarian ulang terjadi pada level atas maka Negascout akan menghasilkan node yang lebih banyak dibandingkan dengan pencarian ulang pada level-level bawah.

d) Berdasarkan pengujian komputer lawan user yang dilakukan dapat dilihat penerapan algoritma Negascout pada permainan Checkers menghasilkan kecerdasan komputer yang hampir sama dengan algoritma Alpha-Beta Pruning dengan waktu respon yang lebih cepat.

e) Berdasarkan pengujian komputer lawan user, komputer memiliki persentase kemenangan lebih besar dengan depth 6 dibandingkan dengan depth 4, sedangkan untuk depth 8 komputer memerlukan waktu terlalu lama sehingga tidak memungkinkan untuk digunakan ketika melawan user.

\subsection{Saran}

Berdasarkan beberapa kelemahan yang dimiliki oleh sistem, penulis memberikan usulan sebagai berikut :

a) Fungsi evaluasi yang digunakan belum cukup bagus, hal ini dapat dilihat dari pengujian kedua dimana komputer masih dapat dikalahkan oleh user. Untuk itu diperlukan fungsi baru yang dapat merepresentasikan kondisi papan lebih akurat untuk menghasilkan A.I. yang lebih baik. Fungsi evaluasi yang digunakan menghitung faktor-faktor seperti : jumlah bidak, jenis bidak, lokasi bidak dan jumlah langkah yang tersedia. Mungkin dengan ditambahkan faktor lain seperti awal permainan atau akhir permainan dapat meningkatkan representasi kondisi papan.

b) Dari 13\% hasil pengujian menunjukkan Negascout menghasilkan jumlah node yang lebih banyak dari Alpha-Beta Pruning. Hal tersebut dikarenakan Negascout melakukan terlalu banyak pencarian ulang yang disebabkan jeleknya move ordering yang ada. Untuk menghasilkan performa Negascout yang lebih baik diperlukan penambahan move ordering yang baik.

\section{Daftar Pustaka}

Ayuningtyas, N. (2008). Algoritma Minimax Dalam Permainan Checkers. Diakses 2 Januari 2012, dari http://informatika.stei.itb.ac.id/ rinaldi.munir/Stmik/2007-2008/Makalah2008/MakalahIF2251-2008-031.pdf

Ertel, W. (2011). Introduction To Artificial Intelligence. Germany: Springer.

Gunawan, Kristian, Y., \& Andika, H. (2009). Game Playing Untuk Othello Dengan Menggunakan Algoritma Negascout dan MTDF. Diakses 2 Januari 2012, dari http://journal.uii.ac.id/index.php/Snati/article/viewFile/1278/1088

Millington, I. (2006). Artificial Intelligence For Games. San Francisco : Morgan Kaufmann.

Reinefeld, A. (1983).An improvement to the scout tree algorithm. Diakses 2 Januari 2012, dari http://www.top5000.nl/ps/An\%20improvement\%20to\%20the\%20scout\%20tree\%20search\%20algorithm.pdf 
Reinfeld, F. (2011). How To Win at Checkers. Diakses 2 Januari 2012, dari http://www.bobnewell.net/checkers/howtowin.pdf

Schaeffer, J. (2009). One Jump Ahead. New York : Springer.

Schaeffer, J., Lake, R. (1996). Solving the Game of Checkers. Diakses 2 Januari 2012, dari http://library.msri.org/books/Book29/files/schaeffer.pdf

Schaeffer, J., Lake, R., Lu, P., \& Bryant, M. (n.d). Chinook : The World Man-Machine Checkers Champion. Diakses 2 Januari 2012, dari http://webdocs.cs.ualberta.ca/ jonathan/publications/ai_publications/aimag96.pdf 